Revue d'histoire du XIXe siècle

Société d'histoire de la révolution de 1848 et des

révolutions du XIXe siècle

$5 \mid 1989$

Histoires de centenaires, ou le devenir des révolutions

\title{
La place de la Semaine sanglante dans la commémoration du centenaire de la Commune en France
}

Alain Dalotel

(Q) OpenEdition

Journals

Electronic version

URL: http://journals.openedition.org/rh19/41

DOI: $10.4000 /$ rh 19.41

ISSN: $1777-5329$

Publisher

La Société de 1848

Printed version

Date of publication: 1 June 1989

ISSN: 1265-1354

\section{Electronic reference}

Alain Dalotel, « La place de la Semaine sanglante dans la commémoration du centenaire de la Commune en France », Revue d'histoire du XIXe siècle [Online], 5 | 1989, Online since 09 September 2008, connection on 03 May 2019. URL : http://journals.openedition.org/rh19/41 ; DOI : 10.4000/ rh19.41

This text was automatically generated on 3 May 2019.

Tous droits réservés 


\title{
La place de la Semaine sanglante dans la commémoration du centenaire de la Commune en France
}

\author{
Alain Dalotel
}

\section{ABSTRACTS}

No abstract available by now

Pas de résumé disponible actuellement

INDEX

Mots-clés: Histoire politique, Commémoration, Semaine sanglante, Répression, Mémoire 